\title{
College students' frequency of use of information sources by fashion leadership and style of information processing
}

\author{
Siwon Cho ${ }^{1 *}$ and Jane E. Workman ${ }^{2}$
}

*Correspondence:

swcho@siu.edu

${ }^{1}$ Fashion Design

and Merchandising

Program, Southern Illinois

University, $311 \mathrm{~F}$ Quigley Hall,

Carbondale, IL 62901-4318,

USA

Full list of author information

is available at the end of the article

\begin{abstract}
Information overload compels consumers to make decisions about how to distribute their limited attention across a variety of information sources. Today's consumers use only one or two information sources from infinite digital choice and search engines available. Thus, it is not a case of more information, but more of the right information that needs to be communicated between consumers and marketers. The purpose of this study was to examine the influences of fashion leadership and style of information processing (SOP) on consumers' frequency of use of information sources for apparel shopping. A survey was conducted using a non-probability sample of 351 US college students. The hypotheses were tested by MANOVA and ANOVA. Results showed that fashion leaders (vs. fashion followers) tended to be greater visualizers who preferred to engage in visual modality of information processing (SOP-visual) for apparel shopping. Fashion leaders (vs. fashion followers) and high visualizers (vs. low visualizers) were more likely to use internal information sources (i.e., experiences and knowledge) as well as impersonal external information sources (e.g., fashion magazines). Results of the study may help apparel marketers in identifying customers' preference for information sources in order to communicate effectively. In turn, apparel consumers may have greater success in their search for reliable, credible, and accessible information. Implications and future research directions are discussed.
\end{abstract}

\section{Introduction}

Information overload occurs when more than the necessary information exists and creates a cognitive burden on the receiver (Malhotra 1982). Information overload compels consumers to make decisions about how to distribute their limited attention across a variety of information sources (Gifford 2001). Malhotra (1982) showed the dysfunctional effects of information overload when consumers are provided with 10 or more alternatives. Information overload contributes to stress and complicates consumers' information processing, sometimes resulting in anxiety, tension, reduced attention span, difficulty remembering information, and poor decision making (Waddington 2003). Today's consumers use only one or two information sources from infinite digital choice and search engines available (Herman and Nicholas, 2010). Thus, it is not a case of more information, but more of the right information that needs to be communicated because consumers seek credible, accessible and reliable information (Carrigan et al. 2004).

(c) 2015 Cho and Workman. This article is distributed under the terms of the Creative Commons Attribution 4.0 International License (http://creativecommons.org/licenses/by/4.0/), which permits unrestricted use, distribution, and reproduction in any medium, provided you give appropriate credit to the original author(s) and the source, provide a link to the Creative Commons license, and indicate if changes were made. 
The Consumer Decision Process Model was developed by Blackwell et al. (2005) to provide an explanation of the process by which consumers make decisions about goods and services. Information search precedes any purchase decision. Typically, consumers use multiple sources of information; each consumer finds a source or combination of sources that work best for him or her. Previous literature shows that more than 60 determinants are related to consumer information search. For example, Schmidt and Spreng (1996) proposed a model of external consumer information search incorporating 22 constructs based on economics, psychological, and motivational approaches. But there is still much unknown about this complex process. Because consumers are bombarded with both visual and verbal information, it is vital to understand how consumers acquire, digest, and divest information (Ramsey and Deeter-Schmelz 2008). Moorthy et al. (1997, p. 276) pointed out "the need for a more careful study of the allocation of search effort across information sources." Researchers examining consumer information search have tried to identify specific categories of antecedent variables that affect consumer information search (e.g., Aydin and Selcuk 2014; Klein and Ford 2003). The perceived value of different information sources is an important issue with implications for marketers. Marketing produces information intended to help attract consumers' attention and contribute to consumer understanding of the benefits of their product. However, the desired effect of positively influencing consumers' decisions is lost if consumers do not pay attention to the information. Thus, understanding consumers' preference for information sources may help firms decide how and where to allocate limited marketing funds.

Among consumer products, the search for pre-purchase information about apparel products is more complex than for some other consumer products. Apparel products are unique because (a) they are evaluated for quality prior to purchase by touching or experience (Lynch et al. 2001), (b) apparel has a strong aesthetic component, therefore, the visual appearance of apparel is critical (Burke 2002), and (c) consumers express their identities and emotions through apparel products (Workman and Freeburg 2009). Previous studies have examined the use of information sources for apparel products by consumers' personal traits such as age, gender, ethnicity, income, and education (e.g., Lumpkin and Festervand 1988; Seock and Bailey 2009; Wilson and MacGillivray 1998; Valdes 2000).

However, there is a gap in previous research regarding how consumers' epistemic values (e.g., curiosity, knowledge, sensory stimulation, variety seeking) influence information search in apparel shopping. Thus, the purpose of the study was to examine the influences of fashion leadership and style of information processing (SOP) on consumers' frequency of use of information sources for apparel shopping. Fashion leadership is a relevant variable in the purchase decision process for apparel products because it is an important personal determinant of apparel shopping preferences (Cho and Workman 2014). SOP is known as an individual consumer's preferred way of processing information (Mueller et al. 2010), which may play an important role in consumers' preference for and use of information sources during apparel shopping. Fashion leadership and SOP were included in the current study because of their conceptual linkages to individual differences and information search in the Consumer Decision Process Model (Blackwell et al. 2005). This study extends the model by specifying influences on apparel consumers' frequency of use of different information sources. Results of the study will help 
marketers understand their target market's individual characteristics and identify customers' preference for information sources in order to communicate effectively. Consequently, apparel consumers may find their information search more efficient without the anxiety and tension arising from information overload.

\section{Literature review}

\section{Conceptual framework}

The Consumer Decision Process Model by Blackwell et al. (2005) describes consumers' decision process behavior from need recognition to satisfaction after purchasing products. The model describes environmental influences and individual differences as factors affecting consumers in all stages of the decision making process. Environmental influences include culture, social class, personal influence, family, and situation. Individual differences are consumer resources, motivation and involvement, knowledge, attitudes, and personality, values, and lifestyles. These factors interact to determine pre-purchase evaluation of alternate products and services and, ultimately, influence consumers' decisions about whether to buy, when to buy, what to buy, where to buy, and how to pay.

Search for information is the second stage in the decision process, which can be either internal or external information search. Experience is the most frequently used internal information when consumers make a purchase decision. External information search involves collecting information from others. It is expected that some consumers may prefer to use internal information, some prefer external information, and others may prefer a combination of both sources. However, the model does not emphasize choice of information source and does not specify what individual differences might influence the use of information sources. The current study looks at consumers' frequency of use of internal and external information sources. Consumers' preference for particular sources of information can be inferred from the frequency with which various sources are used. Thus, this study was developed to examine the influences of individual differences during the second stage in the decision making process, specifically, the influences of individual differences in fashion leadership and SOP on frequency of use of information sources for apparel shopping.

\section{Information sources}

"There are two basic dimensions of consumer information search, internal and external" (Lauraeus-Niinivaara et al. 2007, p. 3). External information sources have been further classified as personal and impersonal (e.g., Barber et al. 2009; Seock and Bailey 2009). Consumers' past experiences provide ideas or images that are useful during an internal information search when consumers retrieve information from memory (Blackwell et al. 2005). Internal information such as prior experience may be the most frequently used source when consumers make a purchase decision. Prior experience, then, may act as a memory schema to influence perceptions of a current situation (Alba and Hasher 1983). If a satisfactory solution becomes clear from relevant information retrieved from memory, then the information search may end before proceeding to an external search. If the necessary information is not available from the internal search, then consumers may widen their search for information to include the external environment. External information search involves collection of information from peers, family, and the commercial 
sphere (Blackwell et al. 2005). External sources include marketer dominated as well as non-marketer dominated sources. Marketer dominated sources include the commercial sphere (i.e., advertising, salespeople, infomercials, websites, point-of-sale materials)marketer-provided information with the intent to persuade consumers to purchase their products. Non-marketer dominated sources include friends, family, opinion leaders, and media-sources over which marketers have little control.

Seock and Bailey (2009) classified these sources as follows: (a) internal information (i.e., experiences and knowledge stored in memory); (b) impersonal external information (i.e., fashion magazines, non-fashion magazines, catalogues, Internet, television ads, celebrities, observed street-wear, and store displays); and (c) personal external information sources (i.e., mother, father, sisters or other female family members, brothers or other male family members, friends, girlfriend or boyfriend, and salespeople at the store). These previously established classifications were included in the current study.

\section{Fashion leadership}

Because the fashion adoption process evolves in stages prompted first by introduction of new styles or variations of existing styles, consumers can be segmented according to fashion leadership as fashion leaders or fashion followers (Workman and Freeburg 2009). Compared to fashion followers, fashion leaders are higher in fashion innovativeness and opinion leadership. Fashion leaders are comprised of three groups that affect the speed and trajectory of fashion adoption: fashion innovators (willing to adopt new fashion styles relatively early in the fashion life cycle), fashion opinion leaders (give advice, act as an information source, and thereby, influence others' purchase decisions), and innovative communicators who combine both roles.

Fashion leaders are more sensitive to and more accepting of fashion change as evidenced by the fact that they are the first to adopt and communicate information about new styles. Fashion followers delay purchasing a new style until later stages of the fashion adoption process. According to Kim and Hong (2011), fashion leadership is a critical consumer trait because the purchase and use of fashion apparel is susceptible to interpersonal influence, especially of fashion leaders. Fashion leaders influence later adopters because they provide exposure to new fashion styles and, by the way they wear and accessorize the new styles, they express and imbue the new fashion styles with meaning (Workman and Freeburg 2009). Fashion leaders are likely to be discerning consumers of information because a new fashion style gets its preliminary meaning (impressions such as professionalism, modesty, femininity, or status) through images and descriptions in advertisements, magazines, and newspaper articles. Most academic research indicates that women are more likely to be fashion leaders than men, although the gender gap may be narrowing with Gen Y.

\section{Style of information processing (SOP)}

According to Barthes (1983), three diverse structures exist for a fashion item-technical (the tangible item), iconic (photograph, picture, or image of the item), and verbal (written or voiced description of the item). SOP is "preference and propensity to engage in a verbal and/or visual modality of processing" (Childers et al. 1985, p. 130). Research in SOP has examined individual tendencies for processing information visually or verbally. 
Word-oriented individuals can be considered high verbalizers: showing high fluency with words, preferring to read about ideas, and enjoying word games. Image-oriented individuals can be considered high visualizers: preferring to view information and enjoying visually-oriented games (Mendelson and Thorson 2004). Generally, consumers prefer visual over verbal processing (Childers et al. 1985; Holbrook 1986); however, limited research has examined SOP related to apparel consumer behavior. The review of literature presents evidence to support four hypothesized relationships among fashion leadership, SOP, and frequency of use of information sources.

\section{Hypotheses development}

\section{Fashion leadership and SOP}

The behavior of fashion leaders and followers differ during different stages of the purchase decision process. For example, during the information search stage, compared with fashion followers, fashion leaders are more likely to read fashion magazines as well as fashion stories in newspapers, watch television programs related to clothing styles, check store availability of clothing shown in magazines, and attend fashion shows (Goldsmith and Flynn, 1992; Goldsmith et al. 1991, 1993; Goldsmith et al. 1999; Quigley and Notarantonio 2009; Uray and Dedeoglu 1998; Vernette 2004). Advertisements, comprising about half of the space in fashion magazines (termed glossy magazines because of the slick paper), are the major source of glossy imagery that provides visual pleasure to readers of fashion magazines (Currie 1997). According to Dyer (1982), readers can more easily understand the visual imagery used in advertisements than the accompanying text. According to Sojka and Giese, exposed to the same advertisement, verbally-oriented consumers focus on the text; visually-oriented consumers focus on the images. Subsequently, verbally-oriented and visually-oriented consumers respond differently to the same advertisement. Thus, SOP preference is likely to influence the second stage of the decision making process, including type of information used as well as extent of information search.

Fashion clothing provides sensory information through sight, touch, kinesthetics, smell, hearing, and taste (Fiore and Kimle 1997). Different consumers have different preferences for sensory forms of information and use different criteria to interpret identical sensory information provided by clothing fashions (Peck and Childers 2003; Workman and Caldwell 2007). For example, fashion leaders consider the image or symbolic (visual) aspects of apparel more important than do fashion followers (Beaudoin et al. 2000). Further, fashion leaders considered visual product aesthetics more central to evaluation of apparel products than fashion followers did (Workman and Caldwell 2007). In addition, need for touch has been defined as a preference for acquiring and using information obtained through the haptic sensory system (Peck and Childers 2003). Fashion leaders were found to have a higher need for touch than fashion followers (Workman 2010; Workman and Cho 2013). Preference for information obtained through touch might affect use of other sensory forms of information, for example, visual (Peck and Childers 2003). Individual differences in traits such as centrality of visual product aesthetics and need for touch have relevance for information search; these traits also differentiate between fashion leaders and fashion followers. 
Thus, individuals who differ in fashion leadership may differ in the frequency with which they use different sources of information during apparel shopping. Evidence has been provided that fashion leaders have a greater need for information overall as well as an active engagement in searching for both visual and verbal information. No research was found that directly examined fashion leadership and SOP. Based on previous related research, fashion leaders and fashion followers were expected to have different styles of information processing. Hypothesis one was proposed.

Hypothesis 1ab. Fashion leaders will have a greater (a) SOP-visual and (b) SOPverbal than fashion followers.

\section{Fashion leadership and information sources}

Fashion leaders have greater need for uniqueness, are more fashion conscious, more interested, and more involved in fashion than are fashion followers (Beaudoin et al. 2000; Phau and Lo 2004; Quigley and Notarantonio 2009; Vernette 2004; Workman and Caldwell 2007; Workman and Cho 2012). Apparel products are products that encourage high involvement, especially among fashion leaders, because of their ability to express an individual's identity and emotions (Workman and Freeburg 2009). Information search might be especially useful with high involvement products (Moorthy et al. 1997).

Fashion knowledgeability (i.e., the amount of fashion information obtained and used by individuals) is another trait with relevance to information search and that separates fashion leaders from fashion followers (Workman and Freeburg 2009). Product knowledge reflects a consumer's prior experience with a product. Fashion leaders are more knowledgeable about fashion because they are more engaged in information seeking (Flynn et al. 1996), go shopping more often (Goldsmith and Flynn 1992; Goldsmith et al. 1991, 1993, 1996, 1999; Stanton and Paolo 2012) and regard magazine advertisements and store displays as important sources of fashion information (Uray and Dedeoglu 1998). Because of these information search activities, fashion leaders are more knowledgeable than fashion followers about fashion product attributes (O'Cass 2004; Goldsmith 2002). Therefore, fashion leaders may have a greater amount of information acquired from marketer-oriented information sources, and consequently, have a greater amount of information stored in memory on which they can rely.

Fashion leaders are key sources of information in interpersonal communication; their friends, family, and other social acquaintances seek their opinion when considering purchase of fashion products (Vernette 2004). Research has found that, compared with fashion followers, fashion leaders have a greater tendency to gossip-one means of sharing their opinions with others (Lee and Workman 2013). Conversely, fashion followers are more likely to ask for others' opinions about fashion topics (Johnson 2008). Based on the research reviewed, fashion leaders and fashion followers were expected to differ in the frequency of use of information sources. Hypothesis two was developed.

Hypothesis 2abc. Fashion leaders will more frequently use (a) internal and (b) impersonal external information sources than fashion followers; fashion followers will more frequently use (c) personal external information sources than fashion leaders. 


\section{SOP and information sources}

Consumers use many sources of information but the combination of information sources that works best for an individual may be influenced by the way he or she absorbs, retains, and processes information, in other words, his or her SOP (Epstein 1998). Although visual and verbal processes have received scrutiny, investigation has focused primarily on SOP in relation to advertising or other product extrinsic cues (e.g., Mueller et al. 2010; Petrova and Cialdini 2005; Ramsey and Deeter-Schmelz 2008). Extrinsic cues are product-linked features that can be changed without changing the product (e.g., price, brand name, or packaging) (Olson and Jacoby 1972). According to Sojka and Giese (2001), high visualizers (vs. low visualizers) are more influenced by visual aesthetic elements in advertisements; the same is likely to be true for other categories of information search. However, there is an absence of research examining how consumers' SOP influences information search in apparel shopping.

Fashion clothing needs to be experienced first-hand via sensory information-especially through the senses of sight and touch (Workman 2010). For example, tactile information is more readily accessible to consumers with a higher need for touch when they search for apparel product information or evaluate product attributes (Peck and Childers 2003). Simultaneously, visual information can present product information briefly (Lurie and Mason 2007), and consumers who enjoy processing image-oriented information can detect and process the information easily (Khakimdjanova and Park 2005). Visual presentation also may help these consumers identify the product and improve their product knowledge. According to Blanco et al. (2010), textual information (i.e., verbal information) improves perceptions of information quality. Thus, consumers who are word-oriented individuals may find it more useful when information about an apparel product is provided in written or voiced description. Based on these notions, it is expected that individuals who have different SOP may use different sources of information during apparel shopping. Hypotheses three and four were developed to examine if degree of SOP-visual and SOP-verbal influences frequency of using sources of information for apparel shopping.

Hypothesis 3abc. Participants high (versus low) in SOP-visual will more frequently use (a) internal, (b) impersonal external, and (c) personal external information sources.

Hypothesis 4abc. Participants high (versus low) in SOP-verbal will more frequently use (a) internal, (b) impersonal external, and (c) personal external information sources.

\section{Method}

\section{Instruments}

Based on the conceptual framework, a questionnaire was developed of measures adopted from previous studies. The questionnaire included demographic items and measures of fashion innovativeness and opinion leadership (Hirschman and Adcock 1978), style of processing (Childers et al. 1985), and sources of information (Seock and Bailey 2009). Demographic items included age, gender, educational level, major, and marital status. 


\section{Fashion leadership}

The Measure of Fashion Innovativeness and Opinion Leadership (Hirschman and Adcock 1978) was selected because it has both content validity and reliability (e.g., .93Workman 2010; .88-Workman and Cho 2012). The 6-item self-report measure has been widely used to measure fashion leadership. An example item is "How often do others turn to you for advice on fashion and clothing?" Each item is accompanied by 5-point response alternatives.

SOP

Childers et al. (1985) developed a 22-item scale to measure preference for SOP (e.g., "I find it helps to think in terms of mental pictures when doing many things."). The scale contains 11 items measuring preference for verbal and 11 items measuring preference for visual styles of processing. Each item is accompanied by a 4-point response alternative. Childers et al. (1985, p. 131) preferred "to compute a single score representing a point on a continuum ranging from visually oriented to verbally oriented processing." With this method of computing a score, participants with both strong visual and verbal processing would be in the middle of the continuum (lack a preference for either style of processing). Childers et al. noted, however, that computing separate scores was an issue worthy of research. We chose to compute separate scores based on the goals of this research. Childers et al. found the SOP scale to have high reliability $(.88)$ as well as discriminant and criterion validity.

\section{Use of information sources}

Sources of information were measured using a scale by Seock and Bailey (2009). Included in the 15-item scale are seven personal external information sources (i.e., mother, father, sisters or other female family members, brothers or other male family members, friends, girlfriend or boyfriend, and salespeople at the store) and eight impersonal external information sources (i.e., fashion magazines, non-fashion magazines, catalogues, internet, television ads, celebrities, observed street-wear, and store displays) of information. Participants indicated on 4-point Likert-type scales how often they seek the opinion of each individual listed as a personal external information source when making a purchase decision on clothing items and how often they use each impersonal external information source when gathering ideas about what clothing items to purchase. Use of internal information source (i.e., oneself) was measured using a 4-point scale for a single item, "How often do you use personal experience as an information source when you make a purchase decision about clothing items?"

\section{Participants, data collection and analysis}

A survey was conducted using a convenience sample of 351 US students from a Midwestern university. Questionnaires were distributed in large lecture classes and took about 15 min to complete. Students received extra credit points for participating. College students themselves represent an important consumer market in terms of numbers and purchasing power. Among 18-24-year-olds, $37 \%$ of men and $42 \%$ of women were in college in 2009 (Fry 2009) and there were 12 million college students in 2012 (Campus life 2012). College students' discretionary income increased to \$120 billion in 2012 
from $\$ 86$ billion in 2011 and $\$ 69$ billion in 2010 (Campus life 2012; Students' consumer clout widens 2010). According to the 2012 College Explorer survey, compared with 2011, spending more than doubled in apparel (up $126 \%$ ), technology (up $227 \%$ ), personal care products (up $105 \%$ ), and cosmetics (up $280 \%$ ) (Campus life 2012). A convenience sample was considered appropriate because generalization to other populations was not intended.

Descriptive statistics were used to report means and standard deviations of the measures. Confirmatory factor analysis (CFA) was used to verify the validity of the measures. Some items in the SOP scale had low factor loadings; only items loading .50 or above were retained for the analysis. Of the 11 items measuring preference for verbal processing, seven were retained; of the 11 items measuring preference for visual processing, ten were retained. Cronbach's alpha reliability was used to verify reliability of the measures. The hypotheses were tested by MANOVA and ANOVA.

\section{Results}

\section{Participant profile and preliminary data analysis}

Participants were 180 women and 171 men $(M$ age $=20.79)$, $88 \%$ were single, from 79 different majors (Fashion Design \& Merchandising major $=19.7 \%$; Other majors $=80.3 \%)$, and all 4 years of school: freshmen $(N=42)$, sophomores $(N=103)$, juniors $(N=92)$ and seniors $(N=114)$. Ethnicity included 122 African Americans, 15 Asian/Asian Americans, 188 Caucasians, 12 Hispanic/Latino, 1 Native American, and 13 otherwise classified.

Reliability of all scales was acceptable. See Table 1 for measurement scale, descriptive statistics, reliability, and factor analysis of variables.

Participants were divided into fashion leaders and fashion followers using a procedure recommended by Hirschman and Adcock (1978). To determine fashion leadership, participants were first categorized as innovative communicators, fashion opinion leaders, fashion innovators, and fashion followers using the mean and standard deviation of scores on fashion innovativeness $(M=7.86 ; S D=2.80)$ and fashion opinion leader$\operatorname{ship}(M=7.39 ; S D=2.98)$. Second, innovative communicators, fashion innovators and fashion opinion leaders were classified as fashion leaders. Other participants were categorized as fashion followers. The procedure classified 99 participants as fashion leaders (74 women, 25 men) and 252 as fashion followers (146 men, 106 women). Women were more likely to be fashion leaders than men $\left[X^{2}(1,351)=30.39 ; p<.001\right]$.

Participants were categorized as high/low visualizers and high/low verbalizers based on the mean score. High visualizers were those who scored 31 or more $(N=174 ; 111$ women, 63 men); low visualizers were those who scored 30 or less $(N=177 ; 108$ men, 69 women). High verbalizers were those who scored 17 or more $(N=170 ; 89$ men, 71 women); low verbalizers were those who scored 16 or less $(N=181 ; 109$ women, 82 men). Women $(M=15.84)$ and men $(M=16.63)$ did not differ in SOP-verbal $[t$ (1, $349)=1.675, p<.095]$. However, women $(M=31.57)$ reported a greater SOP-visual than men $(M=28.71)[t(1,349)=4.48, p<.000]$.

Ratings for frequency of use of mother, father, sisters or other female family members, brothers or other male family members, friends, girlfriend or boyfriend, and salespeople at the store were summed and divided by seven to calculate a mean score for frequency 


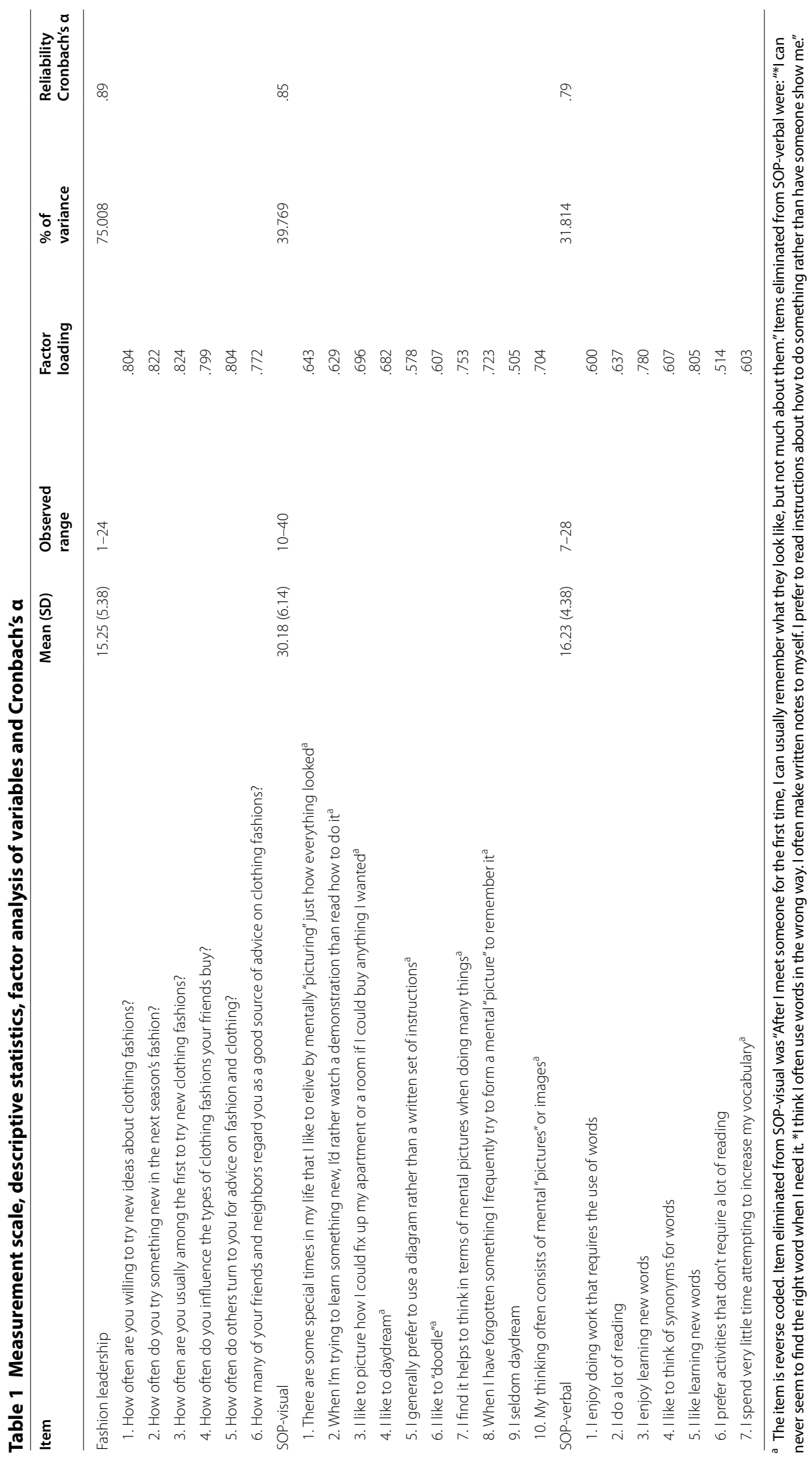


of use of personal external information sources. Ratings for frequency of use of fashion magazines, non-fashion magazines, catalogues, internet, television ads, celebrities, observed street-wear, and store displays were likewise summed and divided by eight to calculate a mean score for frequency of use of impersonal external information sources. Because use of oneself as an information source was measured with a single item on a 4-point scale, no further calculations were necessary to achieve an overall score for frequency of use of internal information source.

\section{Hypotheses testing}

To test hypothesis 1, MANOVA followed by ANOVA was conducted with fashion leadership (fashion leaders, fashion followers) as the independent variable and SOP-visual and SOP-verbal as the dependent variables. MANOVA was significant for fashion leadership $[F(2,348)=6.03, p<.003]$. ANOVA results revealed that fashion leaders $(M=33.41)$ had a greater SOP-visual than fashion followers $(M=31.25)[F(1$, $349)=11.03, p<.001$ ], indicating that fashion leaders are more likely to be visualizers in information processing. H1a was supported. However, fashion leaders $(M=24.73)$ did not differ from fashion followers $(M=25.65)$ on SOP-verbal $[F(1,349)=1.91, p<.167]$. H1b was not supported.

MANOVA followed by ANOVA was conducted to examine $\mathrm{H} 2, \mathrm{H} 3$, and $\mathrm{H} 4$ - the relationships among fashion leadership (fashion leaders, fashion followers), SOP-visual (high visualizers, low visualizers), SOP-verbal (high verbalizers, low verbalizers) and frequency of use of information sources: (a) internal, (b) impersonal external and (c) personal external. MANOVA was significant for fashion leadership $[F(3,341)=18.99$, $p<.000]$, SOP-visual $[F(3,341)=6.11, p<.000]$, and SOP-verbal $[F(3,341)=3.10$, $p<.027]$. There were no significant interactions among variables.

ANOVA results are presented in Table 2. Compared with fashion followers, fashion leaders more frequently used (a) internal and (b) impersonal external information sources but did not differ from fashion followers in frequency of use of (c) personal external information sources. Hypothesis $2 \mathrm{a}$ and $2 \mathrm{~b}$ were supported; hypothesis $2 \mathrm{c}$ was not supported.

ANOVA results showed that participants high (versus low) in SOP-visual more frequently used (a) internal and (b) impersonal external information sources but did not differ in frequency of use of (c) personal external information sources. Hypothesis 3a and $3 \mathrm{~b}$ were supported; hypothesis $3 \mathrm{c}$ was not supported.

ANOVA results revealed significant differences between high verbalizers and low verbalizers in frequency of use of internal sources (see Table 2). Participants low (versus high) in SOP-verbal more frequently used (a) internal sources of information but did not differ in frequency of use of external sources of information either (b) impersonal external or (c) personal external. No further analysis was conducted with SOP-verbal. Hypothesis 4a was supported; hypotheses $4 \mathrm{~b}$ and $4 \mathrm{c}$ were not supported.

Because ANOVA revealed that none of the independent variables was significant for personal external information sources, no further analysis was conducted with this variable. However, to examine specific differences in impersonal external information sources, MANOVA was conducted with fashion leadership (fashion leaders, fashion followers) and SOP-visual (high visualizers, low visualizers) as independent variables and 
eight individual sources of impersonal external information (i.e., fashion magazines, non-fashion magazines, catalogs, internet, television ads, celebrities, observed streetwear, and store displays) as dependent variables. MANOVA results were significant for fashion leadership $[F(8,340)=13.174, p<.000]$ and SOP-visual $[F(8,340)=5.731$, $p<.000]$. There were no significant interactions between fashion leadership and SOPvisual on the dependent variables.

ANOVA results (see Table 3) showed that, compared with fashion followers, fashion leaders more frequently used fashion magazines, non-fashion magazines, catalogs, Internet, television ads, celebrities, observed street-wear, and store displays as sources of information. Further, SOP-visual affected frequency of using fashion magazines, catalogs, observed street-wear, and store displays as impersonal external sources of information (see Table 3). High visualizers more frequently used these information sources than low visualizers. However, high and low visualizers did not differ significantly in use of non-fashion magazines, Internet, television ads, and celebrities.

\section{Discussion and conclusion}

The current study examined the influence of fashion consumers' personal determinants on frequency of use of information sources in apparel shopping. The purpose of this study was to examine the relationships of fashion leadership (fashion leaders, fashion followers), SOP-visual (high visualizers, low visualizers), and SOP-verbal (high verbalizers, low verbalizers) with fashion consumers' frequency of use of information sources (internal, impersonal external, personal external).

Results of the current study revealed that fashion leadership was related to consumers' frequency of use of both internal and impersonal external information sources. Compared to fashion followers, fashion leaders used their previous experience and knowledge from memory for information pertinent to current shopping decisions. Because fashion leaders go shopping more often and are more interested in fashion, they may have built up substantial internal information about apparel products they can subsequently rely on when in need of information. Further, results revealed that fashion leaders used all impersonal external sources of information more frequently than fashion followers. The results indicate that fashion leaders are likely to pay more attention to marketer-dominated information sources; therefore, promotional messages provided by apparel marketers to fashion leaders are important. Results are consistent with previous studies showing the differences between fashion leaders and fashion followers in prepurchase behavior (Beaudoin et al. 2000; Goldsmith 2002; Johnson 2008; Lee and Workman 2013; O'Cass 2004; Vernette 2004; Workman 2010; Workman and Caldwell 2007; Workman and Cho 2012, 2013).

Preliminary analyses of the current study revealed that women and men had equal preference for processing verbal information, but women reported a greater preference for visual information than men. Both women and men preferred visual information more than verbal information confirming the findings of previous research that, in general, people prefer visual information processing (Childers et al. 1985; Holbrook 1986).

Results of the current study further showed that degree of SOP-visual was related to frequency of use of internal and impersonal external information sources. The results are consistent with previous studies showing consumers process and remember visual 
Table 2 ANOVA results for internal, impersonal external and personal external sources of information by fashion leadership, SOP-visual and SOP-visual

\begin{tabular}{|c|c|c|c|c|}
\hline Item & Mean & MS & $F$ & $p<$ \\
\hline \multicolumn{5}{|c|}{ Internal information sources } \\
\hline Fashion leadership & & 7.84 & 14.67 & .000 \\
\hline Fashion leaders & 3.70 & & & \\
\hline Fashion followers & 3.36 & & & \\
\hline SOP-visual & & 5.28 & 9.88 & .002 \\
\hline High visualizers & 3.67 & & & \\
\hline Low visualizers & 3.39 & & & \\
\hline SOP-verbal & & 2.95 & 5.52 & 0.19 \\
\hline High verbalizers & 3.43 & & & \\
\hline Low verbalizers & 3.64 & & & \\
\hline \multicolumn{5}{|c|}{ Impersonal external information sources } \\
\hline Fashion leadership & & 21.51 & 46.95 & .000 \\
\hline Fashion leaders & 2.75 & & & \\
\hline Fashion followers & 2.19 & & & \\
\hline SOP-visual & & 2.38 & 5.18 & .023 \\
\hline High visualizers & 2.56 & & & \\
\hline Low visualizers & 2.37 & & & \\
\hline SOP-Verbal & & 0.41 & .90 & .343 \\
\hline High verbalizers & 2.51 & & & \\
\hline Low verbalizesrs & 2.43 & & & \\
\hline \multicolumn{5}{|c|}{ Personal external information sources } \\
\hline Fashion leadership & & 0.66 & 1.61 & .206 \\
\hline Fashion leaders & 2.31 & & & \\
\hline Fashion followers & 2.21 & & & \\
\hline SOP-visual & & 0.52 & 1.27 & .261 \\
\hline High visualizers & 2.22 & & & \\
\hline Low visualizers & 2.30 & & & \\
\hline SOP-verbal & & 0.27 & .65 & .421 \\
\hline High verbalizers & 2.23 & & & \\
\hline Low verbalizers & 2.29 & & & \\
\hline
\end{tabular}

Degrees of freedom are 1, 343 for all analyses. Fashion leaders $N=99$; fashion followers $N=252$; high visualizers $N=167$; low visualizers $N=184$; high verbalizers $N=170$; low verbalizers $N=181$

information easily, especially in processing information for high involvement products such as apparel (e.g., Khakimdjanova and Park 2005; Lurie and Mason 2007). Compared to low visualizers, high visualizers tend to use internal information sources more often, indicating that these consumers may store mental images of apparel products. The images may be based not only on new information from marketer-dominated information sources but also from their experiences and knowledge retained in memory. In addition, high visualizers more frequently used observed street-wear, store displays, fashion magazines, and catalogs as impersonal external information sources than low visualizers. Similar to the results of fashion leadership, high visualizers may prefer marketer-dominated information where they can obtain professional images reflecting functional and aesthetic product information. For example, store displays are carefully developed by retailers so that customers understand the aesthetic aspects of products as intended. Therefore, high visualizers may appreciate information gleaned from visual 
Table 3 ANOVA results and mean of frequency of using impersonal external sources of information by fashion leadership and SOP-visual

\begin{tabular}{lrrlll}
\hline Item & MS & $\boldsymbol{F}$ & $\boldsymbol{p}<$ & Mean & \\
\hline Fashion leadership & & & & Fashion leaders & Fashion followers \\
Fashion magazines & 74.228 & 69.78 & $.000^{\mathrm{a}}$ & $2.90^{\mathrm{a}}$ & 1.86 \\
Non-fashion magazines & 9.335 & 10.650 & $.001^{\mathrm{a}}$ & $2.08^{\mathrm{a}}$ & 1.71 \\
Catalogs & 7.560 & 7.565 & $.006^{\mathrm{a}}$ & $2.26^{\mathrm{a}}$ & 1.93 \\
Internet & 45.704 & 43.769 & $.000^{\mathrm{a}}$ & $3.42^{\mathrm{a}}$ & 2.59 \\
Television ads & 3.232 & 3.269 & $.071^{\mathrm{a}}$ & $2.34^{\mathrm{a}}$ & 2.12 \\
Celebrities & 52.096 & 47.602 & $.000^{\mathrm{a}}$ & $2.97^{\mathrm{a}}$ & 2.09 \\
Observed street-wear & 9.828 & 9.919 & $.002^{\mathrm{a}}$ & $3.08^{\mathrm{a}}$ & 2.70 \\
Store displays & 11.524 & 11.939 & $.001^{\mathrm{a}}$ & $2.96^{\mathrm{a}}$ & 2.50 \\
SOP-Visual & & & & $H$ High visualizers & Low visualizers \\
Fashion magazines & 13.424 & 12.619 & $.000^{\mathrm{a}}$ & $2.60^{\mathrm{a}}$ & 2.16 \\
Non-fashion magazines & .175 & .200 & .655 & 1.87 & 1.92 \\
Catalogs & 3.542 & 3.544 & $.061^{\mathrm{a}}$ & $2.21^{\mathrm{a}}$ & 1.98 \\
Internet & 2.351 & 2.252 & .134 & 3.10 & 2.92 \\
Television ads & 1.188 & 1.202 & .274 & 2.16 & 2.30 \\
Celebrities & 0.051 & 0.047 & .829 & 2.54 & 2.52 \\
Observed street-wear & 10.807 & 10.908 & $.001^{\mathrm{a}}$ & $3.09^{\mathrm{a}}$ & 2.70 \\
Store displays & 10.231 & 10.599 & $.001^{\mathrm{a}}$ & $2.91^{\mathrm{a}}$ & 2.56 \\
\hline
\end{tabular}

Degrees of freedom are 1, 351 for all analyses. Fashion leaders $N=99$; fashion followers $N=252$; high visualizers $N=174$; low visualizers $\mathrm{N}=177$

a Significant relationships of external sources of information with variables

merchandising and, as a result, understand and remember the acquired visual information better.

In previous research, the importance of personal external information sources has been acknowledged as influential because such information is presumably credible and unbiased-the type of information to which consumers are receptive (Cafferky 2004; Myers and Hufton 2008). Surprisingly, the current study found no significant differences in frequency of use of personal external information sources based on the variables examined (fashion leadership and SOP). It appears that virtually all these participants made use of other people's opinions when searching for information about products. Future research might examine other environmental (e.g., culture) or individual influences (e.g., age) on use of personal external information sources.

The current study highlights the importance of internal information and impersonal external information sources, especially for fashion leaders and individuals who are high in SOP-visual. Results of the study extend the current understanding of frequency of use of information sources by fashion leadership and SOP.

\section{Implications}

Theoretical implications for the Consumer Decision Process Model (Blackwell et al. 2005) result from the current study. This study found that individual differences in fashion leadership and SOP-Visual were factors affecting consumers' frequency of use of internal and impersonal external information sources. Thus, this research affirms and extends the Consumer Decision Process Model regarding the second stage of the 
decision-making process-information search. This study detected previously unidentified individual difference variables related to consumers' frequency of use of information sources.

Results of the current study also provide useful insights for apparel marketers in developing effective marketing strategies according to customers' fashion leadership and SOP. Marketers may offer information through different communication venues and product advertisements. For example, if their target markets are fashion leaders who tend to adopt new fashion styles early and influence others' purchase decisions, visualized information may deliver the message more effectively than text-oriented information because fashion leaders prefer to process image-oriented information. Marketers have successfully advertised in locations that the current study found to be frequently used impersonal external information sources-exposure in fashion magazines and catalogs, and interesting store displays for visual merchandising. Results of the study also reveal the importance of observed street-wear for fashion leaders and visualizers. Therefore, apparel marketers may use blogs or other Internet communication tools to share pictures showing how people fashionably mix and match their products in real life, which provides information related to styling. In addition, apparel marketers may want to take a closer look at the information they send to consumers because it is likely to be stored in memory as knowledge and experiences. Customers may use this knowledge and experience the next time they shop, consequently, information sent to consumers is an opportunity for a company to build a strong and permanent brand or product image.

\section{Limitations and recommendations for future research}

Limitation of the study includes the acceptance of marginally significant results in two instances: fashion leadership-television ads (.07) and SOP-visual-catalogs (.06). These results were consistent with the other results although not quite as strong. However, these marginal results must be considered in interpreting the findings. Limitations of the sample were age (young adults), social status (undergraduate students), and culture (US). Students as participants limit the ability to generalize the results to the larger population of other consumers. This study looked at only one aspect of information search-frequency of use of information sources for apparel shopping.

One finding that points out the need for further research is the lack of discriminant ability for SOP-verbal. Women and men did not differ in SOP-verbal; fashion leaders and fashion followers did not differ in SOP-verbal; high and low SOP-verbal participants did not differ in frequency of use of external sources of information. The only significant finding for SOP-Verbal was that participants low in SOP-verbal more frequently used internal sources of information than participants high in SOP-verbal. Because relying on internal information does not require conversations with others or reading written product information, low verbalizers may feel more comfortable with, and, therefore, prefer processing internal information. Perhaps low SOP-verbal consumers depend on their past experiences with particular brands or stores and satisfy their information needs by depending on brand or store loyalty.

Another perplexing finding regards personal external information sources. There was no difference in frequency of use of personal external information sources based on SOP-visual, SOP-verbal, or fashion leadership. Why no difference in frequency of use of 
personal external information sources? What variables might make a difference in frequency of use of personal external information sources? Further research is needed to understand consumers' use of personal external information sources.

Because of the proliferation of Internet retailing, further research is recommended using the Internet as an impersonal external information source. The information that can be acquired from the Internet needs to be further categorized, for example, product information provided by apparel retailers on store websites needs to be categorized differently than information provided by buyers' feedback on the retailer websites. In addition, information shared through personal blogs and social networking systems such as Facebook, Twitter, and MySpace needs to be categorized among the sources of information from the Internet.

Authors' contributions

SC and JEW designed the research and wrote the manuscript. Both authors read and approved the final manuscript.

Author details

${ }^{1}$ Fashion Design and Merchandising Program, Southern Illinois University, 311F Quigley Hall, Carbondale, IL 62901-4318, USA. ${ }^{2} 2912$ West Kent Drive, Carbondale, IL 62901, USA.

\section{Competing interests}

The authors declare that they have no competing interests.

Received: 20 March 2015 Accepted: 13 November 2015

Published online: 14 December 2015

\section{References}

Alba, J.W, \& Hasher, L. (1983). Is memory schematic? Psychological Bulletin, 93(2), 203-231.

Aydin, A. E., \& Selcuk, E. A. (2014). Consumer information search behavior for experiential and material purchases. Journal of Economics and Behavioral Studies, 6(3), 194-201.

Barber, N., Dodd, T. H., \& Kolyesnikova, N. (2009). Gender differences in information search: Implications for retailing. Journal of Consumer Marketing, 26, 415-426.

Barthes, R. (1983). The fashion system. New York: Hill and Wang/Farrar, Straus, and Giroux.

Beaudoin, P., Moore, M., \& Goldsmith, R. (2000). Fashion leaders' and followers' attitudes toward buying domestic and imported apparel. Clothing and Textiles Research Journal, 18, 56-64.

Blackwell, R. D., Miniard, P. W., \& Engel, J. F. (2005). Consumer behavior (10th ed.). Cincinnatti: South-Western College Publishing.

Blanco, C. F., Sarasa, R. G., \& Sanclemente, C. O. (2010). Effects of visual and textural information in online product presentation: Looking for the best combination in website design. European Journal of Information Systems, 19(6), 668-686.

Burke, R. R. (2002). Technology and the customer interface: What consumers want in the physical and virtual store. Journal of the Academy of Marketing Science, 30(4), 411-432.

Cafferky, M. E. (2004). Managing Word-of-Mouth for Leadership Success. Chicago: Health Administration Press.

Campus life back in session: College students arrive confident, smarter and with climbing consumer spending power. (2012). Globe Newswire, Retrieved May 22, 2013 from http://globenewswire.com/news-rele ase/2012/09/12/490387/10004857/en/Campus-Life-Back-in-Session-College-Students-Arrive-Confident-Smart-erand-With-Climbing-Consumer-Spending-Power.html.

Carrigan, M., Szmigin, I., \& Wright, J. (2004). Shopping for a better world? An interpretive study of the potential for ethical consumption within the older market. Journal of Consumer Marketing, 21(1), 401-417.

Childers, T. L., Houston, M. J., \& Heckler, S. E. (1985). Measurement of individual differences in visual versus verbal information processing. Journal of Consumer Research, 12, 125-134.

Cho, S., \& Workman, J. (2014). Relationships among gender, fashion leadership, need for affect, and consumers' apparel shopping preference. Family and Consumer Sciences Research Journal, 42(4), 369-385.

Currie, D. (1997). Decoding femininity: Advertisements and their teenage readers. Gender \& Society, 11(4), $453-477$.

Dyer, G. (1982). Advertising as Communication. London: Methuen.

Epstein, S. (1998). Emotions and psychology from the perspective of cognitive-experiental self-theory. In W.F. Flack \& J.D. Laird (Eds.), Emothions in psychopathology: Theory and research series in affective sciences (pp. 57-59). New York: Oxford University Press.

Fiore, A. M., \& Kimle, P. A. (1997). Understanding Aesthetics for the Merchandising and Design Professional. New York: Fairchild.

Flynn, L., Goldsmith, R., \& Eastman, J. (1996). Opinion leaders and opinion seekers: Two new measurement scales. Journal of the Academy of Marketing Science, 24(2), 137-147.

Gifford, S. (2001). Endogenous information costs. Social Science Research Network Electronic Library, Retrieved August 14, 2013 from http://papers.ssrn.com/sol13/papers.cfm?abstract_id=262183. 
Goldsmith, R.E. (2002). Explaining and predicting consumer intention to purchase over the internet: an exploratory study. Journal of Marketing Theory and Practice, 10(2), 22-28.

Goldsmith, R., \& Flynn, L. R. (1992). Identifying innovators in consumer product markets. European Journal of Marketing, 26(12), 42-55.

Goldsmith, R.E., Flynn, L.R., \& Moore, M.A. (1996). The self-concept of fashion leaders. Clothing and Textiles Research Journal, 14(4), 242-248.

Goldsmith, R. E., Freiden, J. B., \& Kilsheimer, J. C. (1993). Social values and female fashion leadership: A cross-cultural study. Psychology \& Marketing, 10(5), 399-412.

Goldsmith, R. E., Heitmeyer, J. R., \& Freiden, J. B. (1991). Social values and fashion leadership. Clothing and Textiles Research Journal, 10(1), 37-45.

Goldsmith, R. E., Moore, M. A., \& Beaudoin, P. (1999). Fashion innovativeness and self-concept: A replication. Journal of Product \& Brand Management, 8(1), 7-18.

Herman, E., \& Nicholas, D. (2010). The information enfranchisement of the digital consumer. Aslib Proceedings, 62(3), 245-260.

Hirschman, E., \& Adcock, W. (1978). An examination of innovative communicators, opinion leaders, and innovators of men's fashion apparel. In H. K. Hunt (Ed.), Advances in Consumer Research (pp. 303-314). Ann Arbor: Association for Consumer Research.

Holbrook, M.B. (1986). Aims, concepts, and methods for the presentation of individual differences in esthetic responses to design features. Journal of Consumer Research, 13(December), 337-347.

Johnson, T. W. (2008). Fashion adoption categories: A new investigation of personality facets and demographics. Research Journal of Textile and Apparel, 12(3), 47-55.

Khakimdjanova, L. \& Park, J. (2005). Online visual merchandising practice of apparel e-merchandts. Journal of Retailing and Consumer Services, 12, 307-318.

Kim, H., \& Hong, H. (2011). Fashion leadership and hedonic shopping motivations of female consumers. Clothing \& Textiles Research Journal, 29(4), 314-330.

Klein, L. R., \& Ford, G. T. (2003). Consumer search for information in the digital age: An empirical study of prepurchase search for automobiles. Journal of Interactive Marketing, 17(3), 23-49.

Lauraeus-Niinivaara, T., Saarinen, T., \& Öörni, A. (2007). Knowledge and choice uncertainty affect consumer search and buying behavior: Proceedings of HICSS Conference, pp. 3-7.

Lee, S.-H., \& Workman, J. E. (2013). Gossip, self-monitoring, and fashion consumer groups. Clothing and Textiles Research Journal, 31(2), 67-80.

Lumpkin, J.R., \& Festervand, T.A. (1988). Purchase information sources of the elderly. Journal of Advertising Research, 27, $31-41$.

Lurie, N.H., \& Mason, C. (2007). Visual representation: implications for decision making. Journal of Marketing, 71(1), $160-177$.

Lynch, P. D., Kent, R. J., \& Srinivasan, S. S. (2001). The global Internet shopper: Evidence from shopping tasks in twelve countries. Journal of Advertising Research, 41(3), 15-23.

Malhotra, N. K. (1982). Information load and consumer decision making. Journal of Consumer Research, 8(4), 419-430.

Mendelson, A. L., \&Thorson, E. (2004). How verbalizers and visualizers process the newspaper environment. Journal of Communication, 54(3), 474-490.

Moorthy, S., Ratchford, B. T., \& Talukdar, D. (1997). Consumer information search revisited: Theory and empirical analysis. Journal of Consumer Research, 23(4), 263-276.

Mueller, S., Lockshin, L., \& Louviere, J. (2010). What you see may not be what you get: Asking consumers what matters may not reflect what they choose. Marketing Letters, 21(4), 335-350.

Myers, R.K., \& Hufton, J. (2008). Why manage word-of-mouth? RKM Research \& Communications White Paper Series. Retrieved from http://www.rkm-research.com/whitepaperwom.pdf.

O'Cass, A. (2004). Fashion clothing consumption: antecedents and consequences of fashion clothing involvement. European Journal of Marketing, 38(7), 869-882.

Olson, J.C., \& Jacoby, J. (1972). Cue utilization in the quality perception process. In M. Venkatesan (Ed.), Proceedings of the association for consumer research (pp. 167-179). lowa City: Association for Consumer Research.

Peck, J., \& Childers, T.L. (2003). Individual differences in haptic information processing: the need for touch scale. Journal of Consumer Research, 30(3), 430-442.

Petrova, P. K., \& Cialdini, R. B. (2005). Fluency of consumption imagery and the backfire effects of imagery appeals. Journal of Consumer Research, 32(3), 442-453.

Phau, I., \& Lo, C.-C. (2004). Profiling fashion innovators: A study of self-concept, impulse buying and Internet purchase intent. Journal of Fashion Marketing and Management, 8(4), 399-411.

Quigley, C. J, Jr, \& Notarantonio, E. M. (2009). A cross-cultural comparison of United States and Austrian fashion consumers. Journal of Euromarketing, 8(4), 233-244.

Ramsey, R., \& Deeter-Schmelz, D. (2008). An assessment of the psychometric properties of the styles-of-processing (SOP) scale: How do we measure individuals' verbal/visual information-processing preferences? Journal of Marketing Theory and Practice, 16(1), 41-55.

Schmidt, J. B., \& Spreng, R. A. (1996). A proposed model of external consumer information search. Journal of the Academy of Marketing Science, 24(3), 246-256.

Seock, Y.-K., \& Bailey, L. R. (2009). Fashion promotions in the Hispanic market: Hispanic consumers' use of information sources in apparel shopping. International Journal of Retail \& Distribution Management, 37(2), 161-181.

Sojka, J. Z., \& Giese, J. L. (2001). The influence of personality traits on the processing of visual and verbal information. Marketing Letters, 12(1), 91-106.

Stanton, J., \& Paolo, D. (2012). Information overload in the context of apparel: Effects on confidence, shopper orientation and leadership. Journal of Fashion Marketing and Management, 16(4), 454-476.

Students' consumer clout widens. (2010). Available at http://www.harrisinteractive.com. Retrieved 22 Mar 2011. 
Uray, N., \& Dedeoglu, A. (1998). Identifying fashion clothing innovators by self-report method. Journal of Euromarketing, 6(3), 27-46.

Valdes, I. (2000). Marketing to American Latinos: a guide to the in-culture approach. New York, NY: Paramount Market Publishing.

Vernette, E. (2004). Targeting women's clothing fashion opinion leaders in media planning: An application to magazines. Journal of Advertising Research, 44, 90-107.

Waddington, P. (2003). Dying for information? A report on the effects of information overload in the UK and worldwide. Coalition for Networked Information, Retrieved August 14, 2013 from http://old.cni.org/regconfs/1997/ukoln-content/repor 13.html.

Wilson, J.D., \& MacGillivray, M.S. (1998). Self-perceived influences of family, friends, and media on adolescent clothing choices. Family and Consumer Sciences Research Journal, 26(4), 425-443.

Workman, J. E. (2010). Fashion consumer groups, gender, and need for touch. Clothing and Textiles Research Journal, 28(2), $126-139$.

Workman, J. E., \& Caldwell, L. F. (2007). Centrality of visual product aesthetics, tactile and uniqueness needs of fashion consumers. International Journal of Consumer Studies, 31(6), 589-597.

Workman, J. E., \& Cho, S. (2012). Gender, fashion consumer groups, and shopping orientation. Family and Consumer Sciences Research Journal, 40(3), 267-283.

Workman, J. E., \& Cho, S. (2013). Gender, fashion consumer group, Need for Touch and Korean apparel consumers'shopping channel preference. International Journal of Consumer Studies, 37(5), 522-529.

Workman, J. E., \& Freeburg, B. W. (2009). Dress and Society. New York: Fairchild.

\section{Submit your manuscript to a SpringerOpen ${ }^{\circ}$} journal and benefit from:

- Convenient online submission

- Rigorous peer review

- Immediate publication on acceptance

- Open access: articles freely available online

- High visibility within the field

- Retaining the copyright to your article

Submit your next manuscript at $\mathbf{s p r i n g e r o p e n . c o m ~}$ 